\title{
Community-based food waste modeling and planning framework for urban regions
}

\author{
Ning $\mathrm{Ai}^{\mathrm{a}}{ }^{*}$ and Junjun Zheng $\mathrm{b}$ \\ University of Illinois at Chicago
}

Submitted August 23, 2018 / Revised December 22, 2018, and January 30, 2019 / Accepted January 30, 2019 /

Published online April 30, 2019

Citation: Ai, N., \& Zheng, J. (2019). Community-based food waste modeling and planning framework

for urban regions. Journal of Agriculture, Food Systems, and Community Development, 9(1), 39-58.

https://doi.org/10.5304/jafscd.2019.091.009

Copyright (C) 2019 by the Authors. Published by the Lyson Center for Civic Agriculture and Food Systems. Open access under CC-BY license.

\begin{abstract}
Food waste management (FWM) is a growing challenge in urban regions. Despite increasing concerns about the ensuing environmental pressure, economic inefficiency, and social disparity, quantitative studies of FWM are still limited. This study proposes a scalable model of food waste generation and community-based planning framework that aims to provide data references and policy strategies that help transform urban challenges of FWM into opportunities. In contrast to the existing tools and programs that only focus on large generators (e.g., supermarkets), this study proposes an inclusive approach that also includes small generators (e.g., convenience stores and restaurants) and pairs food waste generators with
\end{abstract}

\footnotetext{
a* Corresponding author: Ning Ai, Department of Urban Planning and Policy and Institute for Environmental Science and Policy, University of Illinois at Chicago; 412 South Peoria Street; Chicago, IL 60607 USA; ain@uic.edu

b Junjun Zheng, Department of Urban Planning and Policy, University of Illinois at Chicago; 412 South Peoria Street; Chicago, IL 60607 USA; jzheng25@uic.edu
}

local users for food reuse and recovery. The generic model was implemented in a case study in Chicago, where residents were found to generate nearly twice as much food waste as businesses on an annual basis. The Chicago case study also demonstrates the spatial mismatch between food waste generators and potential users, suggesting the need of system-wide coordination and planning as well as the inventory modeling at the community level.

\section{Keywords}

Food Waste; Material Flow Analysis; Sustainable Communities; Urban Sustainability; Waste Management

\section{Funding Disclosures}

The authors would like to acknowledge the support from the U.S. National Science Foundation (NSF) under Grant CyberSEES Type II: Data Integration for Urban Metabolism [No. CISE-1331800] and the Great Cities Institute at the University of Illinois at Chicago (UIC). Any opinions, findings, and conclusions or recommendations expressed in this material are those of the authors and do not necessarily reflect the views of the NSF or UIC. 


\section{Note}

One tonne is equivalent to 1,000 kilograms, or 1.102 short tons (as commonly used in the U.S.).

\section{Introduction}

Urban food system planning has drawn increasing attention from researchers, policy-makers, and the public. One in seven people in the U.S., or about 42 million Americans, are food insecure (Feeding America, 2017). Meanwhile, 47.5 million tonnes of food, most of which are actually edible, are discarded each year and end up in landfills (Hoover, 2017; U.S. EPA, 2016a). Only 5\% of discarded food is composted and just $1 \%$ is reused for human consumption (U.S. EPA, 2016a, 2016b). Disposing food discards in landfills not only constitutes an environmental burden, but also limits the recycling of nutrients, such as phosphorous, which is essential for food production and human growth but only exists in finite amounts on Earth (Abdulla, Martin, Gooch, \& Jovel, 2016; Baccini \& Brunner, 2012; Cordell, Drangert, \& White, 2009; Elser \& Bennett, 2011).

The hierarchy of food waste management (FWM) suggests that priority should be given to waste management options with higher-end values in the order of source reduction, human consumption, animal feed, industrial uses, and composting (U.S. EPA, 2012b). Preferable end products can include recovered food for human use, animal feed, soil amendments from composting, and biofuel from anaerobic digestion (Girotto, Alibardi, \& Cossu, 2015; Levkoe \& Wakefield, 2011; Thyberg \& Tonjes, 2016; U.S. EPA, 2012a). Landfilling is the least preferable solution and yet the most commonly employed (U.S. EPA, 2012b).

Existing practices of FWM clearly contribute to economic inefficiency, environmental pressure, and social disparity along the food value chain (Miller et al., 2016). From the perspective of policy making and infrastructure planning, sustainable FWM faces several major barriers. Essentially, uncertainties in food discard volume and quality, in addition to compliance with perceived food safety and public health regulations, contribute to the high cost of planning, handling, and recovery. In addition, emerging FWM regulations and tools have only focused on large generators, such as manufacturers and wholesalers. Small-scale generators (e.g., residents and restaurants), while making up $84 \%$ of total food waste disposal in the U.S. (Business for Social Responsibility [BSR], 2013), are largely unregulated.

Another important gap is the connections between food waste generation and food scrap uses. Composting is often the sole focus of existing food waste diversion programs, but in many cases zoning restrictions and inadequate infrastructure do not support composting activities. Therefore, food waste is co-mingled with other types of municipal solid waste (MSW) and sent to large, remote disposal facilities. As for the strategy of recovering food for the highest potential (i.e., human consumption), a growing number of companies and organizations, such as Feeding America, Spoiler Alert, Zero Percent, Copia (formerly Feeding Forward), Community Plates, and Food Cowboy, have launched programs and technology platforms over the past few years that connect the sellers or donors of surplus food with local partners and food banks. However, the scale of these program remains small; further, citywide or centralized systems that match the excess food with potential uses are lacking. Given the uncertainties about the volume of surplus food at individual locations, decentralized operations present challenges for inefficiencies in collection, drop-off, delivery trips, and, potentially, the reliability and long-term viability of program implementation.

Such challenges in urban areas can be particularly significant given the high density of urban development and large volume of food generation. What is underappreciated, however, is the advantages of density and diversity in urban regions that may help transform these challenges into opportunities in terms of FWM (Figure 1). For example, the prospect of economies of scale in food scrap collection can lead to cost savings. Additionally, urban areas with extensive and diverse businesses (e.g., restaurants, shops, medical centers, and universities) have significant opportunities for alternative FWM strategies (Brinkley, Birch, \& Keating, 2016; Evans-Cowley \& Arroyo-Rodríguez, 2016; Schupp, Getts, \& Otten, 2018). Recovering, recirculating, and reusing waste discards can create new job opportunities and foster community 
Figure 1. Challenges and Opportunities of Food Waste Management (FWM)

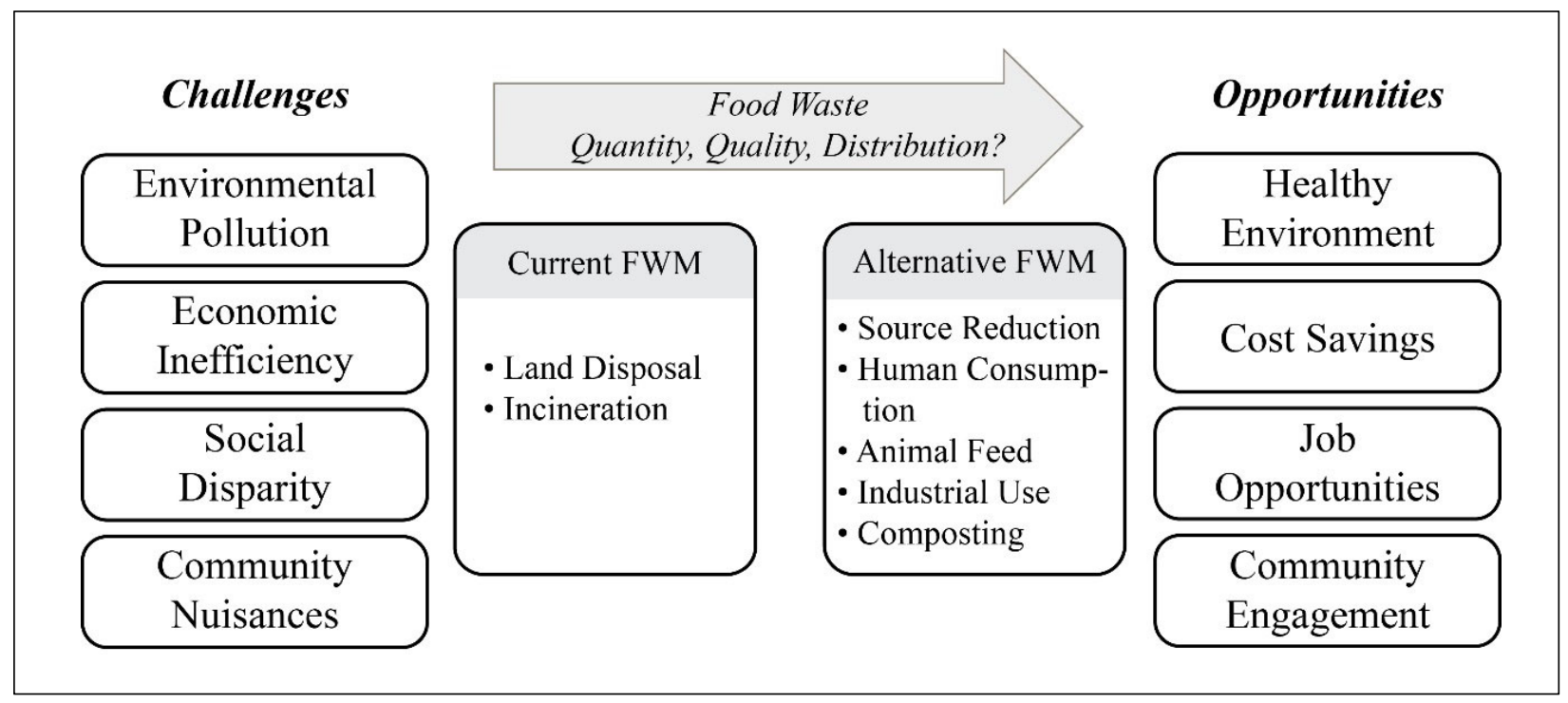

engagement while achieving environmental benefits (Ai \& Leigh, 2017).

Our study directly addresses the unique challenges and opportunities of urban FWM by focusing on four research objectives. First, we aim to develop a generic FWM model that can be adapted to various regions by incorporating communityspecific characteristics, such as mixed types of waste generators, demographics, and existing infrastructure related to food donation and landfill diversion. We believe that better measurement of food waste leads to better design of FWM policies and a better understanding that "one size cannot fit all." Instead of referring to the national or statelevel average when there are waste data constraints, we aim to demonstrate the opportunities for refining food waste estimates and developing placebased strategies. Second, we aim to capture small waste generators in both food waste volume (FWV) estimates and policy design to facilitate their involvement in food recovery programs that are commonly hindered by data constraints and concerns about economies of scale. Third, we aim to foster local alliances and develop communitybased solutions for connecting food waste generators and potential users. Beyond the decentralized programs and platforms discussed above, we aim to provide spatial reference to facilitate systemwide planning and to improve the efficiency of food recovery and recycling. Fourth, and broadly speaking, we aim to add empirical reference to community-based and life-cycle approaches to FWM that are intrinsically connected to food system planning, The following sections in this paper will review the relevant literature, discuss our scalable FWM model for local planning, and provide a case illustration in Chicago.

It is important to note that the scope of this study is largely limited to food discarded by residential, commercial, and institutional sectors. The industrial and wholesale sectors are excluded mainly for two reasons. First, industrial waste is regulated and managed differently from MSW. Its waste planning and collection processes are different; most food producers and wholesalers have established their own logistics chains that include waste management. Second, to reduce landfill disposal costs, the diversion rate of food residuals in industrial sectors is much higher than in other sectors (BSR, 2012). It is the non-industrial sectors that present the highest potential of landfill diversion and thus are focus of this study.

\section{Review of Existing Studies on Food Waste Volume Estimates}

The most fundamental information about food waste, including generation quantity (e.g., weights or bulks), quality (e.g., spoiled or recoverable), 
composition (e.g., water content, energy intensity, and perishable ingredients), and spatial location, is not commonly collected at the source. Consequently, FWV is often estimated using parameters from periodic, small-sample surveys. The U.S. Environmental Protection Agency (U.S. EPA) estimated the national aggregated food waste generation from households and businesses based on a range of survey results from individual states (U.S. EPA, 2014a, 2014b, 2016b). The estimates by Business for Social Responsibility (BSR), a nonprofit organization, also included industries and their recycled food waste before final user consumption (BSR, 2012, 2013, 2014). However, these aggregated data have limited ability to provide local references (e.g., for a city or community) due to heterogeneous conditions. Although MSW characterization studies in some regions include waste audit data for FWV (e.g., CDM, 2010b; IWMB, 2009), inconsistencies in waste definitions, performance indicators (e.g., recycling, recovery, and diversion), and measurement metrics (e.g., per capita or per employee) present a challenge for comparative studies and prevent direct references across jurisdictions. This section reviews these discrepancies as well as common approaches to FWV estimates in a wide range of surveys, numerical studies, and applied tools.

\section{Definition of Food W aste}

Several terms have been adopted in the context of food waste studies, such as food loss, food scraps, and food discards. While these terms are used interchangeably at times, distinctions have been made, particularly between "food loss" and "food waste." Food loss refers to unconsumed, edible food lost throughout the food supply chain, including production, handling, storage, processing, packaging, distribution, and consumption (Buzby, Farah-Wells, \& Hyman, 2014). Food waste, when narrowly defined, refers to the food loss in the distribution and consumption stages, such as leftover discards by consumers and commodity discards by retailers due to undesirable looks or expiration (BSR, 2012, 2013; FAO, 2013; WRAP, 2013). In other words, food waste approximates to food discards and is only part of food loss.
Food waste and food loss can also be measured differently. For example, the U.S. Department of Agriculture (USDA) estimates food loss by focusing on the supply data, or so-called Loss-Adjusted Food Availability (LAFA). For food waste or discards, the U.S. EPA and other organizations (e.g., BSR and ReFED) focus on the consumption side and adopt sectoral adjusted generation factors that are inferred from waste characterization studies.

Another relevant term is "recoverable" food, which we refer to as food discards and surpluses that are still suitable and safe for human consumption. We differentiate recoverable food in our study because it highlights potential opportunities for strategic FWM to achieve even greater benefits than composting and other methods along the FWM hierarchy.

\section{Food W aste Generation and Diversion Rates}

As waste auditing is costly and is not required, local FWV often needs to be estimated assuming a uniform generation rate per person, per meal served, per employee, per square footage of the establishment, or simply for each average-sized establishment in a specific sector. Table 1 summarizes the reported food waste generation, landfill diversion, and disposal rates in the existing literature by generator type (i.e., residential, commercial, and institutional) in various regions.

Residential FWV is typically estimated on a per-capita or per-household basis, although anecdotal studies suggest that the generation rate does vary by demographic characteristics. For example, studies have found that Hispanic households have lower rates than non-Hispanics; lower income households have lower rates than higher income households (Jones, 2004). Younger people and families with children under 18 reported more food discards (Neff, Spiker, \& Truant, 2015). Household size can matter as well; the waste characterization study in Chicago found that a single-family household on average almost doubled the FWV of a multifamily household (CDM, 2010b).

Commercial FWV can be estimated on the basis of employment, establishment size, food products, or sale values (BSR, 2013, 2014; Gustavsson, Cederberg, Sonesson, Otterdijk, \& 
Table 1. Review on Food Waste Parameters by Generator Type

\begin{tabular}{|c|c|c|c|}
\hline Generator Type & $\begin{array}{l}\text { Generation Rate } \\
\text { (Per Unit-Year) }\end{array}$ & $\begin{array}{l}\text { Diversion (DIV), Donation (DON), and/or } \\
\text { Recycling (REC) Rates } \\
\text { (\% or Per Unit-Year) }\end{array}$ & $\begin{array}{l}\text { Disposal Rate } \\
\text { (Per Unit-Year) }\end{array}$ \\
\hline \multicolumn{4}{|c|}{ Commercial } \\
\hline \multirow[t]{3}{*}{$\begin{array}{l}\text { Supermarket/ } \\
\text { Grocery Store/ } \\
\text { Food Store }\end{array}$} & $\begin{array}{l}\text { Employee: 1,360 kg (DLI, 2002; Mercer, } \\
2013 ; \text { ReFED, } 2016) ; 240 \mathrm{~kg} \text { for Retail, } \\
\text { and 2,100 kg for Food Store (CCG, } \\
\text { 2006); } 454 \mathrm{~kg} \text { for Supercenter, and } 10 \\
\text { Tonnes for Wholesale (ReFED, 2016) }\end{array}$ & $\begin{array}{l}\text { DIV 0.5\% (11 kg) for Retail, and DIV } \\
35.2 \% \text { ( } 740 \mathrm{~kg}) \text { for Food Store (CCG, } \\
2006) ; \text { DON 17-35\% for Grocery Retail, } \\
\text { and DIV } 42 \% \text { for Wholesale (ReFED, } \\
2016)\end{array}$ & $\begin{array}{l}1,360 \mathrm{~kg}(\mathrm{CCG}, \\
2006)\end{array}$ \\
\hline & $\begin{array}{l}\text { Store: } 20 \text { Tonnes (Jones, 2004); } 40 \\
\text { Tonnes (Griffin, Sobal, \& Lyson, 2008); } \\
\text { 35-92 Tonnes (Mercer, 2013); 54-490 } \\
\text { Tonnes (U.S. EPA, 2009) }\end{array}$ & $\begin{array}{l}\text { DON 26.3\% and REC 58.9\% (Griffin et } \\
\text { al., 2008); } \\
\text { DIV } 78 \text { Tonnes (LASAN, 2013) }\end{array}$ & $\begin{array}{l}6 \text { Tonnes (Griffin et } \\
\text { al., 2008) }\end{array}$ \\
\hline & $\begin{array}{l}\text { Other: } 4.53 \mathrm{~kg} / \text { Thousand-Dollar-Sales } \\
\text { (BSR, 2014); 1.1-3.4 Tonnes/Thousand } \\
\mathrm{m}^{2} \text { for Shopping Mall (CCG, 2006) }\end{array}$ & $\begin{array}{l}\text { DIV 10-80\%, DON 13.2\%, and REC } \\
29.3 \% \text { (BSR 2014); } \\
\text { DIV 0-0.2\% (CCG, 2006) }\end{array}$ & \\
\hline $\begin{array}{l}\text { Convenience } \\
\text { Store/Small } \\
\text { Grocery Store }\end{array}$ & Store: 8,600 kg (Jones, 2004) & & $\begin{array}{l}621 \mathrm{~kg} \text { for Conven- } \\
\text { ience Store and } \\
1,539 \mathrm{~kg} \text { for Small } \\
\text { Grocery Store } \\
\text { (Griffin et al., 2008) }\end{array}$ \\
\hline \multirow[t]{3}{*}{$\begin{array}{l}\text { Lodging and } \\
\text { Hotels }\end{array}$} & $\begin{array}{l}\text { Employee: } 680 \text { kg (Mercer, 2013; } \\
\text { ReFED, 2016); } 900 \text { kg (CCG, 2006) }\end{array}$ & $\begin{array}{l}\text { DIV 35.2\% (CCG, 2006); REC 70-80\% } \\
\text { (CalRecycle, 2015; LASAN, 2013) }\end{array}$ & $645 \mathrm{~kg}$ (CCG, 2006) \\
\hline & $\begin{array}{l}\text { Store: } 51 \text { Tonnes (Mercer, 2013; } \\
\text { ReFED, 2016); 109-327 Tonnes (U.S. } \\
\text { EPA, 2009) }\end{array}$ & $\begin{array}{l}\text { 163-218 Tonnes (CalRecycle, 2015; } \\
\text { LASAN, 2013) }\end{array}$ & $\begin{array}{l}4 \text { Tonnes (Griffin et } \\
\text { al., 2008) }\end{array}$ \\
\hline & $\begin{array}{l}\text { Other: } 0.45-0.68 \text { kg/Meal (U.S. EPA, } \\
\text { 2009); } 156 \text { kg/Guest-Year (DLI, 2002) }\end{array}$ & & \\
\hline Special Event & $\begin{array}{l}\text { Visitor-Day: 0.18-0.20 kg (CCG, 2006; } \\
\text { DLI, 2002) } \\
\text { Other: } 0.45 \text { kg/Meal or } 0.27 \text { kg/Seat- } \\
\text { Day (DLI, 2002, RecyclingWorks, 2015) }\end{array}$ & $\begin{array}{l}\text { DIV } 1.7 \% \text { (CCG, 2006) } \\
\text { DIV 90\% (NERC, 2010) }\end{array}$ & \\
\hline \multirow[t]{2}{*}{$\begin{array}{l}\text { Full Service } \\
\text { Restaurant }\end{array}$} & $\begin{array}{l}\text { Store: 5,521 Kg (Griffin et al., 2008); } \\
\text { 11-34 Tonnes (EFWN, 2011); 15-30 } \\
\text { Tonnes (Mercer, 2013); } 23 \text { Tonnes } \\
\text { (Jones, 2004); 54-218 Tonnes (U.S. } \\
\text { EPA, 2009) }\end{array}$ & $\begin{array}{l}\text { DON 0.32\% (Griffin et al., 2008); } \\
\text { REC } 33 \text { Tonnes (LASAN, 2013) }\end{array}$ & $\begin{array}{l}5,500 \mathrm{Kg} \text { (Griffin et } \\
\text { al., 2008) }\end{array}$ \\
\hline & $\begin{array}{l}\text { Other: 0.22-0.68 Kg/Meal (DLI, 2002; } \\
\text { Mercer, 2013; ReFED, 2016; U.S. EPA, } \\
\text { 2009); } \\
15 \mathrm{Kg} / \text { Thousand-Dollar (BSR, 2014) }\end{array}$ & $\begin{array}{l}\text { DIV 10-60\%, DON 1.4\%, and REC } 14.3 \% \\
\text { (BSR, 2014) }\end{array}$ & \\
\hline \multirow{2}{*}{$\begin{array}{l}\text { Quick Service } \\
\text { Restaurant/ } \\
\text { Cafeteria/ } \\
\text { Catering Halls }\end{array}$} & $\begin{array}{l}\text { Employee: 1,000 Kg (Mercer, 2013; } \\
\text { ReFED, 2016); 1,130 Kg (CCG, 2006); }\end{array}$ & DIV 13.5\% (CCG, 2006) & $\begin{array}{l}994 \mathrm{Kg}(\mathrm{CCG}, \\
2006)\end{array}$ \\
\hline & $\begin{array}{l}\text { Store: } 12-18 \text { Tonnes (ReFED, 2016); } \\
69 \text { Tonnes (Jones, 2004); 87-326 } \\
\text { Tonnes (U.S. EPA, 2009); }\end{array}$ & & $\begin{array}{l}\text { 6-7 Tonnes (Griffin } \\
\text { et al., 2008) }\end{array}$ \\
\hline $\begin{array}{l}\text { Large/Corporate } \\
\text { Offices }\end{array}$ & $\begin{array}{l}\text { Store: } 87-152 \text { Tonnes (U.S. EPA, 2009) } \\
\text { Other: } 0.22-0.34 \mathrm{Kg} / \text { Meal (U.S. EPA, } \\
\text { 2009); } 1,668 \mathrm{Kg} / \text { Thousand } \mathrm{m}^{2} \text { (CCG, } \\
\text { 2006) }\end{array}$ & & \\
\hline
\end{tabular}


Table 1. Review on Food Waste Parameters by Generator Type (continued)

\begin{tabular}{|c|c|c|c|}
\hline Generator Type & $\begin{array}{l}\text { Generation Rate } \\
\text { (Per Unit-Year) }\end{array}$ & $\begin{array}{l}\text { Diversion (DIV), Donation (DON), and/or } \\
\text { Recycling (REC) Rates } \\
\text { (\% or Per Unit-Year) }\end{array}$ & $\begin{array}{l}\text { Disposal Rate } \\
\text { (Per Unit-Year) }\end{array}$ \\
\hline \multicolumn{4}{|c|}{ Residential } \\
\hline & $\begin{array}{l}\text { Household: } 212 \mathrm{Kg} \text { (Jones, 2004); } 215 \\
\text { Kg (U.S. EPA, } 2009 \text { ); } 143 \mathrm{Kg} \text { for Multi- } \\
\text { Family, and } 298 \mathrm{Kg} \text { for Single-Family } \\
\text { (CDM, 2010b) }\end{array}$ & $\begin{array}{l}\text { REC 41-93 Kg or from 2-5\% to 36-46 \% } \\
\text { (KCl, 2012); REC 46-80 Kg (DSNY, } \\
\text { 2015a, 2015b); REC 165-220 Kg } \\
\text { (Freeman \& Skumatz, 2010) }\end{array}$ & \\
\hline & $\begin{array}{l}\text { Person: } 52 \text { Kg (Griffin et al., 2008); } \\
59 \text { Kg (U.S. EPA, 2014a); } 109 \text { Kg (Jones, } \\
2004)\end{array}$ & REC 2.4\% (Griffin et al., 2008) & \\
\hline \multicolumn{4}{|c|}{ Institutional } \\
\hline Overall & $\begin{array}{l}\text { Store: } 54-327 \text { Tonnes (U.S. EPA, 2009) } \\
\text { Other: 0.34-0.45 Kg/Meal (U.S. EPA, } \\
\text { 2009) }\end{array}$ & & \\
\hline $\begin{array}{l}\text { Elementary and } \\
\text { Secondary } \\
\text { Schools }\end{array}$ & $\begin{array}{l}\text { Student: } 11 \mathrm{Kg} \text { (Mercer, 2013); } 41 \text { kg } \\
\text { (DLI, 2002; Griffin et al., 2008; } \\
\text { RecyclingWorks, 2015) } \\
\text { Employee: } 254 \mathrm{Kg} \text { (ReFED, 2016; Smith, } \\
\text { Shiralipour, \& Kessler, 1998) } \\
\text { Other: } 0.23 \mathrm{Kg} / \mathrm{Meal} \text { (DLI, 2002, Griffin } \\
\text { et al., 2008); 0.10 (Off-site) to 0.25 (On- } \\
\text { site) Kg/Meal (SERA, 2014) }\end{array}$ & $\begin{array}{l}\text { REC 10-25 Tonnes/School (CalRecycle, } \\
\text { 2015; LASAN, 2013; SFRP, 2000) } \\
\text { REC from 18\%-47\% to 56\%-75\% (DSNY, } \\
\text { 2015a, 2015b) }\end{array}$ & \\
\hline $\begin{array}{l}\text { Colleges and } \\
\text { Universities }\end{array}$ & $\begin{array}{l}\text { Student: } 17-64 \text { Kg (RecyclingWorks, } \\
\text { 2015); 34-59 Kg (Griffin et al., 2008) } \\
\text { Employee: } 708 \mathrm{Kg} \text { (CCG, 2006) } \\
\text { Other: } 0.16 \mathrm{Kg} / \mathrm{Meal}(\mathrm{DLI}, 2002 ; \\
\text { RecyclingWorks, 2015) }\end{array}$ & $\begin{array}{l}\text { DON } 0.5 \% \text { and REC } 22 \%-50 \% \text { (Griffin et } \\
\text { al., 2008) } \\
\text { DIV } 8.16 \mathrm{Kg} / \text { Person (LASAN, 2013) }\end{array}$ & \\
\hline $\begin{array}{l}\text { Correctional } \\
\text { Facilities }\end{array}$ & $\begin{array}{l}\text { Person: } 163 \mathrm{Kg} \text { (ReFED, 2016); } 166 \text { kg } \\
\text { (DLI, 2002; Griffin et al., 2008) }\end{array}$ & & \\
\hline Hospital & $\begin{array}{l}\text { Bed: } 566 \text { Kg (DLI, 2002; Griffin et al., } \\
\text { 2008; RecyclingWorks, 2015); 680- } \\
\text { 1,225 Kg (Mercer, 2013) } \\
\text { Site: } 9-152 \text { Tonnes (U.S. EPA, 2009) } \\
\text { Other: 0.23-0.45 Kg/Meal } \\
\text { (RecyclingWorks, 2015; U.S. EPA, 2009) }\end{array}$ & & \\
\hline Nursing Homes & $\begin{array}{l}\text { Bed: 298-331 Kg (DLI 2002; Griffin et } \\
\text { al., 2008; Mercer, 2013; ReFED, 2016) } \\
\text { Site: 33-98 Tonnes (U.S. EPA, 2009) } \\
\text { Other: 0.27-0.50 Kg/Meal (Griffin et al., } \\
\text { 2008; Mercer, 2013; RecyclingWorks, } \\
\text { 2015; ReFED, 2016); 0.34-0.45 } \\
\text { Kg/Meal (U.S. EPA, 2009) }\end{array}$ & & \\
\hline
\end{tabular}

Meybeck, 2011; Parfitt, Barthel, \& Macnaughton, 2010). Understandably, the generation rates vary considerably within this broadly defined sector. Thus, some studies separate food retail sale stores (e.g., grocery store, supermarket and convenience stores) from food service establishments (e.g., restaurants or hotels). For special events, FWV can be estimated based on the number of visitors, seats, or meals (CCG, 2006; DLI, 2002;

RecyclingWorks, 2015). In particular, studies have consistently found that the food discard ratio of small generators (e.g., convenience stores) is much higher than generators in supermarkets, mostly due to their limited flows (CCG, 2006; Griffin, Sobal, \& Lyson, 2008; Gruber, Holweg, \& Teller, 2016). Therefore, alternative approaches to FWM in small 
businesses present significant opportunities for food waste diversion from landfills.

Institutional food waste generators include schools, universities and colleges, hospitals, nursing homes, and correctional facilities. FWV from these facilities is often estimated per capita or bed. On a per-capita basis, universities or colleges with oncampus housing are considered to generate more food waste than those without dorms (Griffin et al., 2008; RecyclingWorks, 2015).

Major gaps are present in landfill diversion and recycling statistics, in terms of both definition clarity and data availability. The statistics related to diversion tend to leave out food donation, and focus on food waste reused for human and/or animal consumption, recycled for compost, or recovered for biogas. Existing programs suggest that the food waste diversion rates are generally low, especially for household discards (DSNY, 2015a, 2015b; KCI, 2012). Institutions tend to achieve the highest diversion rates (about 50\%) (CalRecycle, 2015; DSNY, 2015a, 2015b; LASAN, 2013; SFRP, 2000). As presented in Table 1, food waste generation and diversion rates vary greatly by sector and region, which demonstrates the need for community-specific and sector-specific estimates.

\section{Existing Tools of FWM}

At the facility and regional level, multiple tools have been developed to facilitate FWM, such as the U.S. EPA Food Waste Management Cost Calculator, Food Waste Biogas Economic Model, and the continuously updated Waste Reduction Model (WARM) (U.S. EPA, 2009, 2010, 2016c). These tools can be used by individual waste generators to conduct a cost-benefit analysis or by local government and organizations to quantify the connection between waste management methods and greenhouse gas emissions. However, these tools have focused on a region-wide estimate based on fixed parameters; they have also focused on single facilities in the category of medium or large food waste generators. However, small food waste generators, such as residential or small commercial sites, are typically excluded.

There has also been some limited use of geographic information systems (GIS) to map the spatial distribution of food waste generators, such as those in the states of Connecticut, Massachusetts, Pennsylvania, and Virginia (DLI, 2002; DLI \& AGC, 2001; DuPage County, 2012; VANR, 2014). Those tools, however, are also limited to medium and large generators. Moreover, those tools typically rely on self-reported data from businesses or from private consulting firms, such as Dun and Bradstreet. Therefore, the public has limited access to data sources for regular updates (U.S. EPA, 2012c).

By excluding small generators, the existing tools do not seem to address the full scope of food waste. This limitation hinders potential collaborations among generators within their surrounding communities. Robust references at refined geographical scales are largely lacking, which presents a major challenge for food scrap collection and recovery. More importantly, food waste generators and food banks (as an example of potential users) are often examined separately. To achieve efficient and effective FWM through economies of scale, it is important to set up various levels of collaboration among different waste generators in a community.

\section{Integrated Model of Community-Level Food Waste Management}

To help fill the data gap and planning references for local FWM, we propose a scalable model for FWV estimates and FWM program development. The model is designed to be adaptable in specific communities (e.g., ZIP Codes or city neighborhoods) as well as cities and counties. The quantitative analysis in this study will adopt the material flow analysis approach and focus on retail and consumer food discards-i.e., "food waste" as defined above. For the aforementioned reasons explained in the first section, industrial generators are not included in the numerical analysis. The generic model entails the eight steps as follows.

(1) Characterize Waste Generators. The categorization of waste generators can be contingent upon local and regional FWM practices, pertinent programs and regulations, and data availability. It is common to adopt three general categories-e.g., residential, commercial, and institutional. Specific subcategories (as shown in Table 1) may vary by 
community and region. They need to be identified, differentiated, and modeled, especially when large variations of FWV within the subcategory are expected. The adoption of publicly accessible data sets, such as those from national statistical institutions (e.g., the American Community Survey or ZIP Code Business Pattern from the U.S. Census Bureau), state and county agencies (e.g., department of health), and municipalities (e.g., the city of Chicago data portal), enables the model implementation of FWV modeling over time and comparison across communities.

\section{(2) Determining a Geographic Unit of Analy-}

sis. The choice of the unit of analysis of FWM can depend on both the research purpose and data availability, although the results from disaggregated results can always be aggregated. FWV estimates of individual buildings, businesses, or households allows for advanced programming, such as routing optimization for collection and donation pick-ups. However, existing data may not always support such a detailed analysis. In addition, FWV from individual generators may vary over time (e.g., weekdays vs. weekends). Aggregated results at an intermediate level (e.g., communities or ZIP Codes) as a lump sum can help control the relative uncertainties in individual behaviors and still be appropriate for logistics planning.

\section{(3) Select a Causal Parameter for Generation}

Rates Estimates. The unit generation rates (e.g., per capita, household, or employee), when coupled with local characteristics, provide a potential opportunity to refine estimates of discarded materials (Leigh et al., 2007). Theoretically, the parameter should be the primary factor that minimizes the variation in FWV estimates within the specific generator group (e.g., meals served for fast food restaurants; number of people for residential discards). In practice, the determination of a unit can be largely constrained by data availability. For example, data about employment and establishment size can be more commonly available than meals served or sale receipts at each establishment.

(4) Model Total FWV. With food discard rates and generator information in each subcategory, the total volume of food discards can be modeled mathematically as illustrated in Equation (1). When local or regional waste characterization data are available, the estimates can potentially be validated. Given uncertainties in FWV, a sensitivity analysis is also needed. Examples of data validation and sensitivity analysis will be provided in Section 4.

$$
\begin{aligned}
& V_{\text {Waste }}=\sum_{i=1}^{3} \sum_{j=1}^{C_{i}} f_{i j}\left(V_{1}, V_{2}, \ldots, V_{m}\right) \times N_{i j} \text { (1) } \\
& \text { Where, } \\
& V_{\text {waste: Food waste generation (by weight); }} \\
& i: \text { Generator type ( } i=1 \text { Residential; } i=2 \text { Commercial; } \\
& \quad i=3 \text { Institutional); } \\
& j: \text { Sub-categories of each generator type, such as } S F \text { and } \\
& \quad M F \text { of residential generators (detailed categories in } \\
& \text { Table 1); } \\
& C_{i:} \text { Number of sub-categories of generator type } i ; \\
& f_{i j}(): \text { Food waste generation rate for sub-category } j \text { of } \\
& \text { generator type } i ; \\
& N_{i j:} \text { Number of units (e.g., employees or establishments) } \\
& \text { in sub-category j of category } i ; \\
& V_{1}, V_{2}, \ldots, V_{m} \text { : causal factors of food waste } \\
& \text { generation; }
\end{aligned}
$$

(5) Estimate Recoverable FWV. Building upon Equation (1), Equation (2) calculates the FWV that is potentially recoverable or reusable by waste generator type. Adopting a recovery rate based on the reported data of existing and emerging practices (as in Table 1) can lead to a benchmark of recovery potential. A region may also have set its diversion goals that include a targeting recovery rate.

$$
\begin{aligned}
& V_{\text {Potential }}= \\
& \sum_{i=1}^{3} \sum_{j=1}^{C_{i}} g_{i j}\left(R_{1}, R_{2}, \ldots, R_{m}\right) \times V_{\text {waste } i j}
\end{aligned}
$$

Where,

$$
\begin{aligned}
& V_{\text {potential: }} \text { Food waste recovery potential volume (by } \\
& \text { weight); } \\
& i: \text { Generator type ( } i=1 \text { Residential; } i=2 \text { Commercial; } \\
& \quad i=3 \text { Institutional); } \\
& j: \text { Sub-categories of each generator type, such as SF and } \\
& \quad M F \text { of residential generators (detailed categories in } \\
& \quad \text { Table 1); } \\
& C_{i:} \text { Number of sub-categories of generator type } i \text {; } \\
& g_{i j}(\text { : Food waste recovery rate for sub-category } j \text { of }
\end{aligned}
$$




\section{business category $i$; \\ $R_{1}, R_{2}, \ldots, R_{m}$ : causal factors of food waste recovery; \\ $V_{\text {waste: }}$ Food waste generation (by weight).}

(6) Identify Potential Demand for Recoverable Food Discards. An inventory of potential demand for food discards, corresponding to the FWM hierarchy (e.g., food banks, soup kitchens, farms, and composting facilities), should be investigated in the proximity of food waste generation. Data can be typically obtained from public agencies and nonprofit organizations, such as Feeding America (a national network of food banks). When food recovery networks are further developed, the inventory of potential demand can also include food processing facilities and other commercial enterprises. These are enterprises that can process recoverable food into value-added products through creative recipe research and development, as demonstrated in the pilot program in Philadelphia (O'Donnell, Deutsch, Yungmann, Zeitz, \& Katz, 2015).

\section{(7) Spatially Match Food Discards and FW} Recovery Options. Communities are likely to either have high donation potential or desire more supply at the food banks. Pairing up the surplus and shortage areas that are in closest proximity to each other provides a local solution that reduces the transportation distance while helping to address the community's disparities in food security. This final step employs a GIS analysis to connect the potential "demand" in response to the "supply" derived from Equation (2). Subsequently, planners can identify areas that tend to generate a large FWV but do not have food diversion facilities. Such areas may need new infrastructure for food donation, composting, drop off, or mobile services for food scrap collection. Likewise, existing locations of food recovery centers (e.g., food banks) can identify potential partners (e.g., institutions and community centers) for food pick-ups.

To identify such a mismatch, this study proposes a food waste Supply-Demand Index (SDI), which is calculated as the difference between the Food Supply Index and the Food Demand Index. The Food Supply Index is calculated by the percentile value (0 to 1 ) of food donation potential density in a given community. The Food Demand Index is calculated by the percentile value of food bank density in a given community. The frequency distribution of SDI values across neighborhoods or communities can provide references for the determination of SDI threshold values. For example, by referring to the histogram (Appendix), it would make sense to determine the SDI threshold values to be \pm 0.25 . In other words, if the SDI is larger than 0.25 , we assume that food discard volume is higher than the demand from food banks, and so the area is categorized as the "Surplus." Likewise, if the SDI is lower than -0.25 , we assume that the area needs more food donations and thus it is categorize as the "Shortage."

\section{Case Implementation in Chicago}

The city of Chicago hosts 2.7 million residents, 1.45 million jobs, and 78,000 business establishments (U.S. Census Bureau, 2012) that all contribute to food waste generation. According to the Chicago Waste Characterization and Diversion study, only $2 \%$ of food waste is currently recovered; 498,800 tonnes of food waste end up in landfills each year (CDM, 2010a). The Illinois Food Scrap Coalition (IFSC) found several challenges to food waste diversion from landfills in the Chicago area, including insufficient education, the cheap landfill cost, missing demand and end market, a lack of infrastructure, and the unstable quality of food waste (IFSC, 2015). Meanwhile, the enactment of Illinois Senate Bill 99 in 2009 has simplified permit applications for composting facilities, which are not licensed currently to accept food waste. Small start-up programs for alternative FWM have been rapidly developing within the region, including vertical farms and biogas production that utilize food waste. There are also more than 300 food banks within the city boundaries. Therefore, we determined that implementing our FWM model in Chicago may lead to a timely and relevant reference for planning.

\section{Data Inputs}

To determine the quantity and spatial distribution of FWV, we first developed an inventory for all buildings that may generate food waste. Table 2 below shows the citywide summary statistics for 
each generator or building type. Table 2 also shows the data parameters that were adopted for FWV estimates, which are intended to be relatively lower compared to existing and emerging practices. Conservative estimates were developed to make sure potential environmental benefits from landfill diversion and food recovery would not be exaggerated. We used the parameters in Table 2 for estimating FWV at the establishment and household level and then aggregated the results for community- and city-level discussions.

\section{Results of FWV Estimates}

As a conservative estimate derived from Equation (1), the city of Chicago generates 409,400 tonnes of food scraps a year. About 242,700 tonnes of food discards come from residences, 133,000 tonnes from businesses, and 33,700 tonnes from

Table 2. Chicago FW Generator Summary and Modeling Parameters

\begin{tabular}{|c|c|c|c|c|c|}
\hline & $\begin{array}{l}\text { No. of } \\
\text { Establish- } \\
\text { ments }\end{array}$ & $\begin{array}{l}\text { Unit of Analysis } \\
\text { for FWV } \\
\text { Estimates }\end{array}$ & $\begin{array}{l}\text { Total No. of } \\
\text { Units }\end{array}$ & Generation Rate & $\begin{array}{l}\text { Donation } \\
\text { Potential }\end{array}$ \\
\hline \multicolumn{6}{|l|}{ Residential a } \\
\hline Single Family & - & Housing Unit & 618,361 & 298 Kg/Unit-Year & \multirow[t]{2}{*}{ DON: $1.4 \%$} \\
\hline Multifamily & - & Housing Unit & 408,988 & 143 Kg/Unit-Year & \\
\hline \multicolumn{6}{|l|}{ Commercial b } \\
\hline $\begin{array}{l}\text { Supermarkets, department stores and large } \\
\text { food retail sales (FOSAL1) }\end{array}$ & 622 & Employee & 25,773 & 1,360 Kg/Employee-Year & \multirow[t]{2}{*}{ DON: $18 \%$} \\
\hline $\begin{array}{l}\text { Convenience stores, small grocery stores, } \\
\text { gas stations, and other food retail sales } \\
\text { (FOSAL2) }\end{array}$ & 1,595 & Employee & 4,253 & 1,360 Kg/Employee-Year & \\
\hline Hotels (FOSVC1) & 97 & Employee & 776 & 1,020 Kg/Employee-Year & \multirow[t]{5}{*}{ DON: $1.4 \%$} \\
\hline $\begin{array}{l}\text { Full service restaurants, fine dining places } \\
\text { and similar food service retailers (FOSVC2) }\end{array}$ & 2,135 & Employee & 37,171 & 1,020 Kg/Employee-Year & \\
\hline $\begin{array}{l}\text { Limit service restaurants, fast food } \\
\text { restaurants, and similar food service retails } \\
\text { (FOSVC3) }\end{array}$ & 2,363 & Employee & 19,369 & 1,020 Kg/Employee-Year & \\
\hline $\begin{array}{l}\text { Cafeteria, coffee shop and other food service } \\
\text { retails (FOSVC4) }\end{array}$ & 1,582 & Employee & 11,810 & 1020 Kg/Employee-Year & \\
\hline Office building (OFFICE) & 157 & Thousand $\mathrm{m}^{2}$ & 12,983 & $\begin{array}{c}1,668 \mathrm{Kg} / \text { Thousand } \\
\mathrm{m}^{2}-\text { Year }\end{array}$ & \\
\hline \multicolumn{6}{|l|}{ Institution } \\
\hline $\begin{array}{l}\text { Private/public primary/secondary schools } \\
(\mathrm{SCH})^{c}\end{array}$ & 1,033 & Student & 478,247 & $28.6 \mathrm{Kg} /$ Student-Year & \multirow[t]{5}{*}{ DON: $1.4 \%$} \\
\hline University with on-campus housing (UNIV1) d & 23 & Student & 137,461 & $52.2 \mathrm{Kg} /$ Student-Year & \\
\hline $\begin{array}{l}\text { University without on-campus housing } \\
(\text { UNIV2)d }\end{array}$ & 59 & Student & 113,693 & $17.2 \mathrm{Kg} /$ Student-Year & \\
\hline Hospitals (HOSP) e & 38 & Bed & 10,080 & 566 Kg/Bed-Year & \\
\hline Nursing Facilities (NSG) ${ }^{f}$ & 120 & Bed & 17,321 & 298 Kg/Bed-Year & \\
\hline
\end{tabular}

Data sources: a The numbers of single- and multifamily households are from U.S. Census Bureau American Community Survey (ACS) 5-year estimates (2008-2013); b the data for commercial subcategories are from business license database and food inspection database provided by the city of Chicago; subcontract services are excluded due to data constraints; ${ }^{\mathrm{C}}$ the data for K-12 schools, including private and public primary schools and secondary schools in Chicago, are from the city of Chicago data portal; $d$ the data for universities and colleges are from National Center for Education Statistics, including location, student enrollment, and campus housing; e the data for hospitals (e.g. location and number of licensed beds) are from Illinois Health Facilities and Services Review Board; $f$ the data for nursing facilities (e.g., location and number of licensed beds) are from the Illinois Department of Public Health (IDPH). 
institutions. The FWV from residents is nearly double that of businesses, demonstrating the need to include households in food waste reduction efforts.

There are 77 communities in Chicago; on average, a community hosts 35,200 people (CMAP, 2017). At the community level, FWV ranges widely from 252 tonnes to 32,120 tonnes. Three communities (the Loop, Near North Side, and Near West Side) generated 20,000 tonnes or greater of food waste annually. Five additional communities generate more than 10,000 tonnes and are clustered in the north and center of the city. Overall, the communities in the north of the city generate greater FWV than the communities in the south, which corresponds to the spatial disparities of economic conditions (Figure 2, left). In total, 27 out of 77 communities generate more than 5,000 tonnes per year, which would require one truck every day to separately collect all the food scraps. Notably, the waste composition from the three types of generators varies, even when communities generate similar FWV. Because the recovery potential varies by sector (e.g., higher in businesses than residence), preferable FWM methods may vary across communities.

In terms of density, the central business district (CBD), not surprisingly, shows the highest FWV, at over $7,500 \mathrm{~kg} / \mathrm{km}^{2}$ (Figure 2). Areas along the northern coast and the Chicago O'Hare international airport also present a high density of FWV. The north side of the city includes more communities with high-density FWV than the south. But the south does have a few "hot spots," which could be preferable locations for drop-off centers or arranged pick-up service, especially when an extensive curbside program is not available. FWV Result Validation

There are no other studies or statistics of FWV available at the community level. When aggregated to the city level, our results can be validated by the waste audit data documented in the Chicago Waste Characterization and Diversion study (CDM, 2010a; 2010b). Comparison by each sector and generator type is not straightforward, however, due to inconsistencies in the sector and generator classification. Table 3 presents a cross-walk of the generator categories. Generally speaking, the FWV

\section{Figure 2. Food Waste Generation in Chicago Communities}

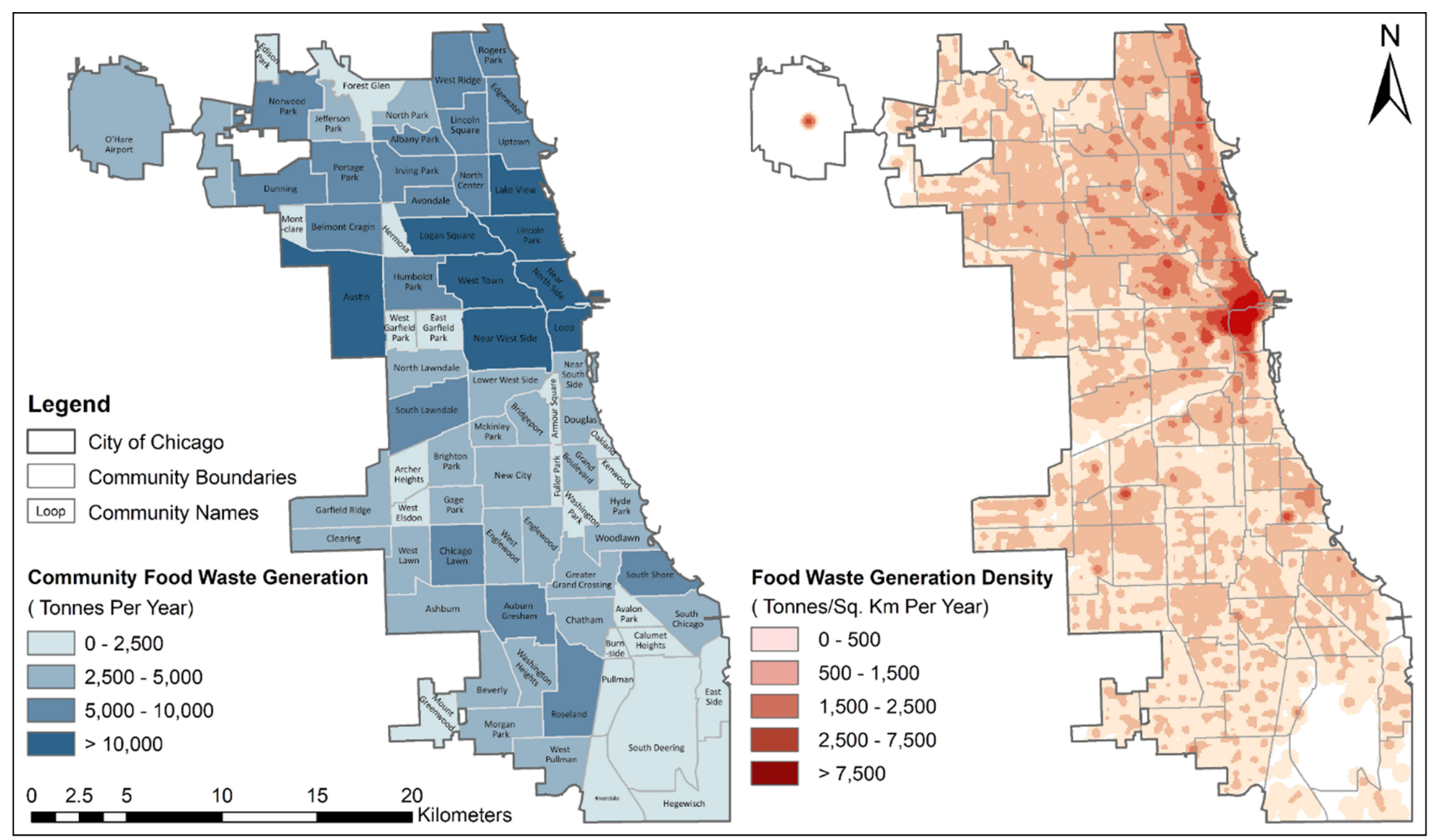


estimates resulting from our study show a comparable magnitude at the city level in comparison to the city's reported findings. As expected, our study presents slightly lower estimates, given that we have adopted a conservative generation rate.

\section{Sensitivity Analysis}

To address uncertainties in food waste generation rates of individual generators (e.g., weekdays vs. weekends), we have employed the Monte Carlo (MC) simulation method for a sensitivity analysis. In total, 200 interactions of MC simulation were computed to obtain the statistics at three uncertainty levels and for three FWV rates-i.e., $\pm 20 \%$, $\pm 30 \%$, and $\pm 50 \%$ of average generation rates and donation potential. For example, at $\pm 20 \%$ variation of the generation rate, input parameters vary randomly from $80 \%$ to $120 \%$ of the average generation rates in the MC simulation. The coefficient of variance $(\mathrm{CV})$, the ratio of standard deviation $(\sigma)$ to the mean $(\mu)$, is calculated to measure the impact of uncertainties on total FWV (Equation 3). The greater the uncertainty level is, the greater the CVs can be.

$$
C V=\frac{\sigma}{\mu}
$$

At $\pm 20 \%$ variation of citywide generation rates, the $\mathrm{CV}$ is $0.18 \%$. At $\pm 50 \%$ variation on individual generation rates - that is, if individuals generate from $50 \%$ to $150 \%$ of the average rate-it yields $2.47 \%$ variance in citywide food waste generation. The CVs for donation volume seem to be even smaller than that of the total generation volume. The MC simulation suggests that variations among individual generation rates have negligible impacts on the total FWV at the city level, and thus they also have negligible impact on the donation potential.

Similar MC simulations were also run at the community level. The CVs can be up to $18.88 \%$ at the uncertainty level of $\pm 50 \%$ of the average generation rates. Understandably, communities with fewer generators or smaller FWV yield higher CVs. But in general, the average CVs are $1.99 \%$ at $\pm 20 \%$ variation, $2.98 \%$ at $\pm 30 \%$ variation, and $5.09 \%$ at $\pm 50 \%$ variation. These findings suggest that a community could be an appropriate unit for FWM, where the uncertainties in FWV are manageable and economies of scale of FWM are attainable.

\section{Matching Demand and Supply}

The FWM hierarchy suggests reuse as the most desirable approach. Therefore, this study focuses on food donations and food banks as examples of "supply" and "demand," respectively. Additionally, this study takes advantage of point-level FWV estimates when mapping the spatial pattern of supply and demand. The same approach can be applied for other linkages, such as food scrap clusters with local composting facilities or urban community gardens.

Derived from Equation (2), at least 12,900 tonnes of food discards by Chicagoans are recoverable for human use per year. Understandably, the majority of recoverable food $(69.45 \%)$ is derived from the commercial sector. Households, while individually showing a relatively low recovery rate, in aggregated terms account for about one-fourth of total donation potential. Institutions account for $3.62 \%$ of total food waste donation. For individual communities, the donation potential ranges widely from 6 tonnes to 790 tonnes annually, with an average volume of 160 tonnes.

Given that the geographic size of any individual community is rather large and varies across the city, understanding the absolute tonnage of FWV is not enough. The density map shown in Figure 3 can help identify specific locations for efficient pick-ups of recoverable food, such as those with the highest potential donation density at over 250 tonnes per $\mathrm{km}^{2}$.

Clearly the locations with a high density of recoverable food do not match the demand for food donation-e.g., food banks (indicated by yellow dots in Figure 3). The results of the SDI in Chicago are presented in Figure 4. Generally, the food surplus communities cluster in the central and northern part of city, as well as along the south branch of the Chicago River. The food shortage communities cluster in the west side of the city and the northern part. The map provides empirical evidence of community disparities, which can be addressed by citywide coordination efforts. For example, once the generation origin and volume of food discards are identified, an appropriate 
collection method can be implemented to facilitate food scrap recycling from small generators, such as curbside programs, co-collection of food waste and yard waste, drop-off centers, or kitchen pails.

\section{Conclusion and Discussions}

Despite the increasing attention to the food waste challenge, quantitative studies of FWM are still limited, especially at the community level. This study proposes an FWM modeling and planning framework that aims to provide data references and policy insights into community-level FWM.

The case implementation in Chicago demonstrates

\section{Figure 3. Spatial Distribution of Food Waste Donation Potential and Its} Potential Users

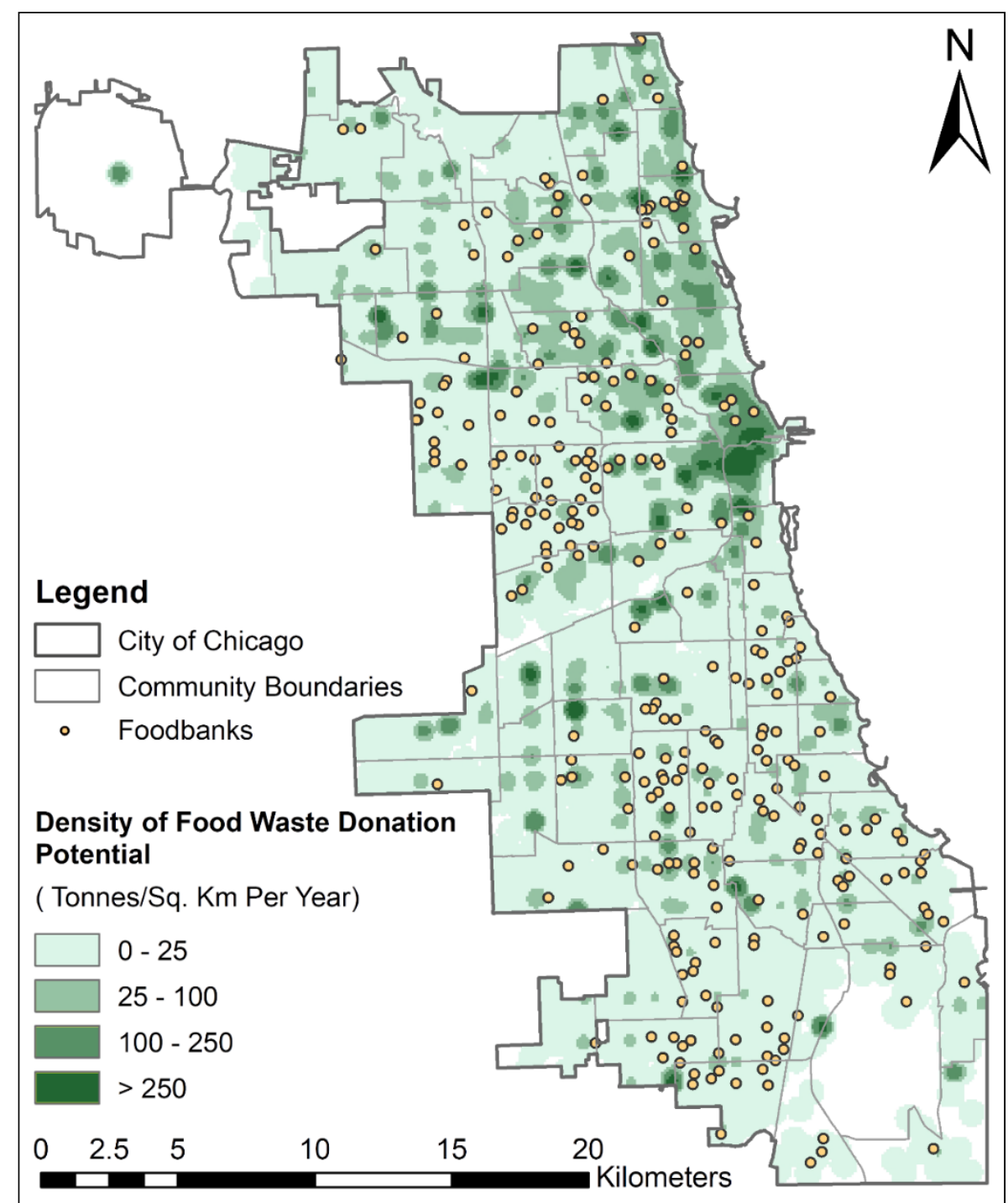

the potential opportunities for urban planners to promote the efficiency, effectiveness, and equity goals surrounding FWM. Notably, in regards to food waste, and waste in general, people tend to adhere to an "out of sight, out of mind" mentality. The system modeling and planning framework in this study could increase the visibility of food waste challenges that could be integrated with other food system planning programs (e.g., those related to food insecurity, food dessert, and nutrient loss), and helping to close the loop of food systems.

FWM necessitates a thorough understanding of waste origin and volume, which is only periodically recorded through the waste auditing process in some regions. This study demonstrated the feasibility of producing reasonably accurate estimates of FWV by employing publicly accessible data sets. The FWV model also allows communities to incorporate their unique characteristics and enables comparison across different regions with a relatively consistent approach.

Further, the sensitivity analysis in the Chicago case implementation suggests that the uncertainties of FWV estimates can be manageable at a relatively small geographical scale. The refined volume estimates, as discussed in this study, can provide critical information to help improve the performance of FWM. For example, planning can focus on the communities that present the highest food donation potential as pilot locations. Planning can also 
design food scrap collection infrastructure strategically based on the FWV and composition of waste generators in order to facilitate reuse and recycling programs at the community level. "Hot spots" of FWV could serve as the anchors of food recovery locations, instead of contributing to environmental injustice.

This study has demonstrated the importance of engaging small food waste generators in alternative FWM programs. As concluded in the case study, residences generate nearly twice as much FWV as businesses and contribute to more than one-third of the total recoverable food in Chicago. An inclusive approach of FWM will not only improve the accuracy in inventory modeling, but also present potential opportunities for community-specific implementation. Adopting an inclusive FWM framework can foster a bottomup approach for FWM. Participatory approaches to FWM also present potential opportunities for educating communities, enhancing FW data accuracy, fostering organized networks, and implementing a preferred hierarchy of FWM efficiently.

Most importantly, our proposed FWM modeling and planning framework promote local solutions to FWM by connecting food waste generators and potential users. The information derived from our proposed model aims to facilitate collaboration among residents, businesses, and institutions as community consortia in minimizing food waste disposal. By connecting food scrap generation
Figure 4. Spatial Matching of Food Waste Donation Potential and Food Banks by Chicago Community Areas

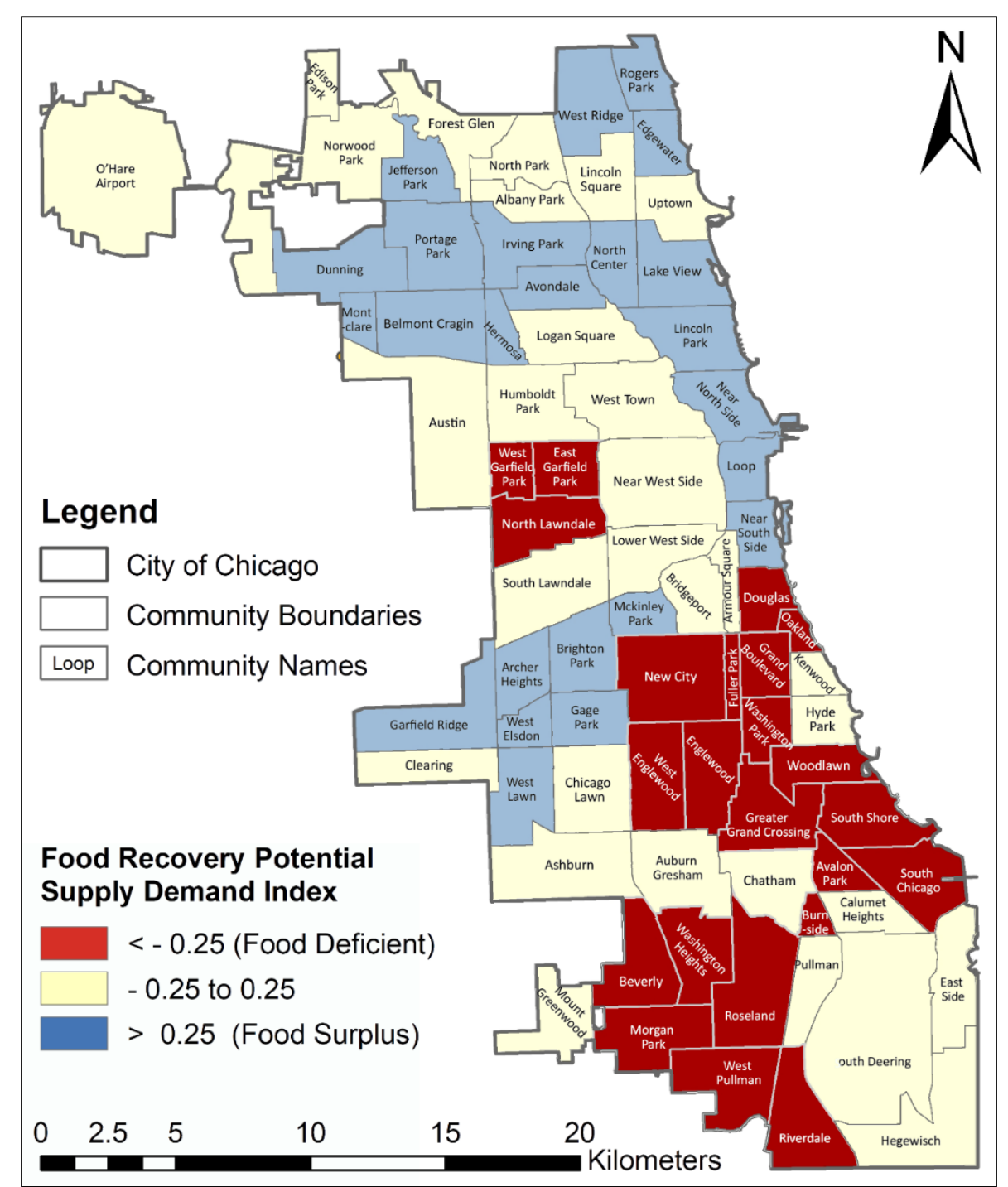

with reuse and recovery options, this study demonstrates empirical evidence of spatial mismatch. FWM efficiencies and social equity goals can be further improved if planning can pair up food surplus and shortage communities strategically, although further analysis is still needed to examine collection and transportation strategies as well as their ensuing impacts.

We anticipate that developing communityspecific FWM models, involving local stakeholders, and disseminating the results would also increase the awareness of food waste problems and provide valuable references for public education, which 
have been identified as key solutions to address barriers of food waste diversions and to promote best-practice programs (Freeman \& Skumatz, 2010; Neff et al., 2015). Improving and/or increasing communication between local communities and food recovery networks would also provide valuable opportunities for data validation, which currently has limited options, as previously discussed above. In particular, additional information from residents and business owners in the planning process can help refine the estimates for small food waste generators. Besides quantity, the quality of food scraps is crucial for determining the range of options for food scrap recovery and reuse. Uncertainties about the quality over time and across seasons make food scraps particularly difficult to model compared to products with longer life spans (e.g., e-waste and automobile tires). Sharing data by the community on food purchasing and consumption behaviors is key to addressing constraints and uncertainties on food data.

Future work and greater data availability could help expand the proposed FWM modeling and planning framework. Our numerical models can be adapted to market dynamics and technology advancement by, for example, adjusting the generation rate and recovery rate. After the modeling results are validated, the data references that we have developed could enable transportation logistics analyses that explore efficient strategies to match food shortage and surplus. In addition, testing the model in other regions could reveal the heterogeneities in food flows and correspondingly provide empirical references for region-specific hierarchy solutions for FWM.

To conclude, it is important to further clarify that food waste prevention necessitates both food discard recovery and source reduction. Essentially, our hypothesis is that better measurement of the location and volume of excess food helps prevent food waste. Our numerical analysis and planning framework have focused on food recovery, or "recoverable food," in addition to addressing food waste in general. Strategies for source reduction involve many more complex factors (e.g., technology, economic incentives and/or disincentives, behavioral issues related to culture, religion, and diet). Although not the focus of this study, source reduction would make economic sense as the first step of sustainable FWM, instead of managing food already produced, distributed, purchased, and discarded. Compared to the logistics planning of food recovery trips, however, food purchasing and consumption behaviors may not be easily influenced by public policies in the short term. This suggests that the cost effectiveness of FWM strategies may vary by temporal as well as geographic scopes. While the benefits of community-based planning strategies discussed here may be more predictable, and we may be able to see those benefits sooner than those of source reduction programs, source reduction should be a continuous and long-term planning goal.

\section{Acknowledgements}

The authors would like to acknowledge the assistance received from Anthony Farruggia and Katheryn Borucki.

\section{References}

Abdulla, M., Martin, R., Gooch, M., \& Jovel, E. (2016). The importance of quantifying food waste in Canada. Journal of Agriculture, Food Systems, and Community Development, 3(2), 137-151. https://doi.org/10.5304/jafscd.2013.032.018

Ai, N., \& Leigh, N. G. (2017). Planning for sustainable material and waste management (Planning Advisory Service Report No. 587). Chicago: American Planning Association. Executive summary available online: https://www.planning.org/publications/report/9124041/

Baccini, P., \& Brunner, P. H. (2012). Metabolism of the Anthroposphere: Analysis, evaluation, design (2nd ed.). Cambridge, MA: MIT Press. https://doi.org/10.7551/mitpress/8720.001.0001

Brinkley, C., Birch, E., \& Keating, A. (2016). Feeding cities: Charting a research and practice agenda toward food security. Journal of Agriculture, Food Systems, and Community Development, 3(4), 81-87. https://doi.org/10.5304/jafscd.2013.034.008

Business for Social Responsibility [BSR]. (2012). Food waste: Tier 1 assessment. Food Waste Reduction Alliance. Retrieved from http://www.foodwastealliance.org/wp-content/uploads/2013/06/FWRA BSR Tier1 FINAL.pdf 
BSR. (2013). Analysis of US food waste among food manufacturers, retailers, and wholesalers. Food Waste Reduction Alliance. Retrieved from http://www.foodwastealliance.org/wp-content/uploads/2013/06/FWRA BSR Tier2 FINAL.pdf

BSR. (2014). Analysis of US food waste among food manufacturers, retailers, and restaurants. Food Waste Reduction Alliance. Retrieved from http://www.foodwastealliance.org/wp-content/uploads/2014/11/FWRA BSR Tier3 FINAL.pdf

Buzby, J. C., Farah-Wells, H., \& Hyman, J. (2014). The estimated amount, value, and calories of postharvest food losses at the retail and consumer levels in the United States (EIB-121). U. S Department of Agriculture, Economic Research Service. https://doi.org/10.2139/ssrn.2501659

California's Department of Resources Recycling and Recovery [CalRecycle]. (2015). Food Scraps Management Case Studies (Model Programs). Retrieved August 10, 2017 from https://www.calrecycle.ca.gov/Organics/Food/CaseStudies/

Cascadia Consulting Group [CCG]. (2006). Targeted statewide waste characterization study: Waste disposal and diversion findings for selected industry groups: Contractor's report to the board. California Integrated Waste Management Board (CIWMB). Retrieved from https://www2.calrecycle.ca.gov/Publications/Download/787

CDM. (2010a). Chicago waste diversion study. Chicago Department of Environment. Retrieved from https://www.cityofchicago.org/content/dam/city/depts/doe/general/RecyclingAndWasteMgmt PDFs/WasteAn dDiversionStudy/WasteDiversionStudyReport2.pdf

CDM. (2010b). Waste characterization study. Chicago Department of Environment. Retrieved from https://www.cityofchicago.org/content/dam/city/depts/doe/general/RecyclingAndWasteMgmt PDFs/WasteAn dDiversionStudy/WasteCharacterizationReport.pdf

Chicago Metropolitan Agency for Planning [CMAP]. (2017). Community data snapshots. The CMAP Data Hub. Retrieved from https://datahub.cmap.illinois.gov/dataset/community-data-snapshots-raw-data

Cordell, D., Drangert, J., \& White, S. (2009). The story of phosphorus: Global food security and food for thought. Global Environmental Change, 19(2), 292-305. http://dx.doi.org/10.1016/i.gloenvcha.2008.10.009

Department of Sanitation at City of New York [DSNY]. (2015a). Diversion Report II: NYC organics collection pilot, AprilSeptember 2014. Retrieved from https://www1.nyc.gov/assets/dsny/docs/about OrganicsCollection-LL77DiversionReportII-2015 0815.pdf

DSNY. (2015b). Diversion Report III: NYC organics collection pilot, October 2014 - April 2015. Retrieved from https://www1.nyc.gov/assets/dsny/docs/about_LL77_DiversionReportIII_June2015_0815.pdf

Draper/Lennon, Inc. [DLI]. (2002). Identification, characterization, and mapping of food waste and food waste generators in Massachusetts. Massachusetts Department of Environmental Protection. Retrieved from https://www.mass.gov/files/documents/2016/08/qn/foodwast.pdf

DLI \& Atlantic Geoscience Corp. [AGC]. (2001). Identifying, quantifying, and mapping food residuals from Connecticut businesses and institutions: an organics Recycling Planning Tool Using GIS. Connecticut Department of Environmental Protection. Retrieved from http://www.ct.gov/deep/lib/deep/compost/ssomfile/ssomreport.pdf

DuPage County. (2012). Northeast Illinois Compost Locations. DuPage County Open GIS Data.. Retrieved August 10, 2017, from http://dupage.maps.arcgis.com/apps/OnePane/basicviewer/index.html?appid=3a5936a07751 4821977c04bd689ec3c2

Elser, J., \& Bennett, E. (2011). Phosphorus cycle: A broken biogeochemical cycle. Nature, 478(7367), $29-31$. http://doi.org/10.1038/478029a

End Food Waste Now [EFWN]. (2011). End food waste: Facts. Retrieved May 8, 2015, from http://www.endfoodwastenow.org/index.php/resources/facts but no longer available online. Hard copy in possession of authors.

Evans-Cowley, J. S., \& Arroyo-Rodríguez, A. (2016). Integrating food waste diversion into food systems planning: A case study of the Mississippi Gulf Coast. Journal of Agriculture, Food Systems, and Community Development, 3(3), $167-185$. https://doi.org/10.5304/jafscd.2013.033.003

Feeding America. (2017). Map the Meal Gap 2017: Highlights of findings for overall and child food insecurity. Retrieved from http://www.feedingamerica.org/research/map-the-meal-gap/2015/2015-mapthemealgap-exec-summary.pdf 
Journal of Agriculture, Food Systems, and Community Development

ISSN: 2152-0801 online

https://www.foodsystemsjournal.org

Food and Agriculture Organization of the United Nations [FAO]. (2013). Food wastage footprint: Impacts on natural resources: Summary report. Rome: Food and Agriculture Organization of the United Nations. Retrieved from http://www.fao.org/3/i3347e/i3347e.pdf

Freeman, J., \& Skumatz, L. A. (2010). Best management practices in food scraps programs. U.S. Environmental Protection Agency Region 5. Retrieved from http://www.foodscrapsrecovery.com/EPA_FoodWasteReport_EI_Region5_v11_Final.pdf

Girotto, F., Alibardi, L., \& Cossu, R. (2015). Food waste generation and industrial uses: A review. Waste Management, 45, 32-41. https://doi.org/10.1016/j.wasman.2015.06.008

Griffin, M., Sobal, J., \& Lyson, T. A. (2008). An analysis of a community food waste stream. Agriculture and Human Values, 26(1-2), 67-81. https://doi.org/10.1007/s10460-008-9178-1

Gruber, V., Holweg, C., \& Teller, C. (2016). What a waste! Exploring the human reality of food waste from the store manager's perspective. Journal of Public Policy and Marketing, 35(1), 3-25. https://doi.org/10.1509/ippm.14.095

Gustavsson, J., Cederberg, C., Sonesson, U., Otterdijk, R. V., \& Meybeck, A. (2011). Global food losses and food waste: Extent, causes and prevention. Rome: Food and Agriculture Organization of the United Nations.

Hoover, D. (2017). Estimating quantities and types of food waste at the city level. Natural Resources Defense Council. Retrieved from https://www.nrdc.org/sites/default/files/food-waste-city-level-report.pdf

Illinois Food Scrap Coalition [IFSC]. (2015). Food scrap composting challenges and solutions in Illinois report. Retrieved from http://illinoiscomposts.org/files/IFSC-FoodScrapReportFINAL-Jan2015.pdf

Integrated Waste Management Board, California [IWMB]. (2009). California 2008 statewide waste characterization study. California Environmental Protection Agency. Retrieved from https://www2.calrecycle.ca.gov/Publications/Download/911

Jones, T. W. (2004). Using contemporary archaeology and applied anthropology to understand food loss in the American food system. University of Arizona, Bureau of Applied Research in Anthropology. Retrieved from https://humwp.ucsc.edu/gleaningstories/pdf/jones foodwaste.pdf

Kessler Consulting, Inc. [KCI]. (2012). Mecklenburg County, NC food waste diversion study: Final report. Mecklenburg County Solid Waste Reduction/Composting. Retrieved from https://www.mecknc.gov/LUESA/SolidWaste/Documents/Food\%20Waste\%20Diversion\%20Study\%20Final.pdf

LA Sanitation, City of Los Angeles [LASAN]. (2013). Zero waste progress report. Retrieved from https://planning.lacity.org/eir/8150Sunset/References/4.K.3.\%20Solid\%20Waste/SW.04_Zero\%20Waste\%20Pro gress\%20Report March\%202013.pdf

Leigh, N. G., Realff, M. J., Ai, N., French, S. P., Ross, C. L., \& Bras, B. (2007). Modeling obsolete computer stock under regional data constraints: An Atlanta case study. Resources, Conservation and Recycling, 51(4), 847-869. https://doi.org/10.1016/j.resconrec.2007.01.007

Levkoe, C. Z., \& Wakefield, S. (2011). The Community Food Centre: Creating space for a just, sustainable, and healthy food system. Journal of Agriculture, Food Systems, and Community Development, 2(1), 249-268.

https://doi.org/10.5304/jafscd.2011.021.012

Mercer, A. G. (2013). Assessment of food waste generation in Mercer County, New Jersey. Alternative Energy Innovation Center, Bordentown, New Jersey. Retrieved from http:/ / envirostewards.rutgers.edu/alumniassociation/PDFs /An $\% 20$ Assessment $\% 20$ of $\% 20$ Food $\% 20$ Waste $\% 20$ Ge nerated $\% 20$ in $\% 20$ Mercer $\% 20$ County $\% 200122 \% 2013$.pdf

Miller, M., Anderson, M., Francis, C., Kruger, C., Barford, C., Park, J.\& McCown, B. H. (2016). Critical research needs for successful food systems adaptation to climate change. Journal of Agriculture, Food Systems, and Community Development, 3(4), 161-175. https://doi.org/10.5304/jafscd.2013.034.016

Neff, R. A., Spiker, M. L., \& Truant, P. L. (2015). Wasted food: US consumers' reported awareness, attitudes, and behaviors. PloS One, 10(6), e0127881. https://doi.org/10.1371/journal.pone.0127881

Northeast Recycling Council [NERC]. (2010). Guidance for special event food waste diversion. Northeast Recycling Council. Retrieved from https://nerc.org/documents/guidance for special event food waste diversion.pdf 
O’Donnell, T. H., Deutsch, J., Yungmann, C., Zeitz, A., \& Katz, S. H. (2015). New sustainable market opportunities for surplus food: A food system-sensitive methodology (FSSM). Food and Nutrition Sciences, 6(10), 883-892. https://doi.org/10.4236/fns.2015.610093

Parfitt, J., Barthel, M., \& Macnaughton, S. (2010). Food waste within food supply chains: Quantification and potential for change to 2050. Philosophical Transactions of the Royal Society B: Biological Sciences, 365(1554), 3065-81. https://doi.org/10.1098/rstb.2010.0126

RecyclingWorks. (2015). Food waste estimation guide. Recycling Works Massachusetts. Retrieved August 11, 2017, from http://www.recyclingworksma.com/food-waste-estimation-guide/\#Jump06

ReFED. (2016). A roadmap to reduce U.S. food waste by 20 percent. Rethink Food Waste Through Economics and Data. Retrieved from https://www.refed.com/downloads/ReFED Report 2016.pdf

San Francisco Recycling Program [SFRP]. (2000). City of San Francisco food waste diversion pilot program. City of San Francisco. Retrieved from https://www.calrecycle.ca.gov/docs/cr/Organics/food/SanFran2.pdf

Schupp, C. L., Getts, K. M., \& Otten, J. J. (2018). An evaluation of current lunchroom food waste and food rescue programs in a Washington state school district. Journal of Agriculture, Food Systems, and Community Development, 8(1), 167-186. https://doi.org/10.5304/jafscd.2018.081.013

Skumatz Economic Research Associates [SERA]. (2014). The costs and benefits of Minnesota K-12 school waste management program. Retrieved from https://www.pca.state.mn.us/sites/default/files/p-p2s6-15.pdf

Smith, W. H., Shiralipour, A., \& Kessler, M. (1998). Final report: Food waste diversion in Florida. University of Florida Institute of Food and Agricultural Sciences Center for Biomass Programs and Florida Organic Recyclers Association. Retrieved from http://www.floridaforce.org/wp-content/uploads/2019/04/Food-Waste-Diversionin-Florida-Final-Report.pdf

Thyberg, K. L., \& Tonjes. D. J. (2016). Drivers of food waste and their implications for sustainable policy development. Resources, Conservation and Recycling, 106, 110-123. https://doi.org/10.1016/j.resconrec.2015.11.016

U.S. Census Bureau. (2012). All sectors: Geographic area series: Economy-wide key statistics: 2012 [Table]. 2012 Economic Census of the United States. The data are searchable by interactive table at https://factfinder.census.gov/faces/nav/jsf/pages/index.xhtml

U.S. Environmental Protection Agency [U.S. EPA]. (2009). Food waste management cost calculator, version 1.0. Retrieved February 2019 from https://www.epa.gov/sites/production/files/2017-01/foodcost3.xls

U.S. EPA. (2010). Food waste biogas economic model. U.S. Environmental Protection Agency Region 9. Retrieved February, 2014, from https://archive.epa.gov/region9/organics/web/xls/epa-food-waste-biogas-economic-model.xls

U.S. EPA. (2012a). Putting surplus food to good use. Retrieved from https://archive.epa.gov/wastes/conserve/tools/rogo/web/pdf/food-guide.pdf

U.S. EPA. (2012b). Food scrap recycling: A primer for understanding large-scale food scrap recycling technologies for urban areas. Retrieved from http://www.ct.gov/deep/lib/deep/compost/compost pdf/large scale food scrap recycling primer epa.pdf

U.S. EPA. (2012c). Updated mapping of food residual generation in Connecticut: Final report. Retrieved from http://www.ct.gov/deep/lib/deep/compost/compost_pdf/ct_food_residual_generator_report_2012.pdf

U.S. EPA. (2014a). Municipal solid waste in the United States facts and figures: A methodology document. Retrieved from https://www.epa.gov/sites/production/files/2015$12 /$ documents/methodolgy document for selected municipal solid waste products.pdf

U.S. EPA. (2014b). Reducing wasted food and packaging: A guide for food services and restaurants. Retrieved from https://www.epa.gov/sites/production/files/2015-08/documents/reducing wasted food pkg tool.pdf

U.S. EPA. (2016a). Advancing sustainable materials management: 2014 fact sheet. Retrieved from https://www.epa.gov/sites/production/files/2016-11/documents/2014 smmfactsheet 508.pdf

U.S. EPA. (2016b). Food waste management in the United States, 2014. U.S. Environmental Protection Agency, Office of Resource Conservation and Recovery. Retrieved from https://www.epa.gov/sites/production/files/201612/documents/food waste management 2014 12082016 508.pdf

U.S. EPA. (2016c). Waste reduction model. Retrieved from https://www.epa.gov/warm/versions-waste-reduction-model$\underline{\text { warm }}$ 
Journal of Agriculture, Food Systems, and Community Development ISSN: 2152-0801 online

https://www.foodsystemsjournal.org

Vermont Agency of Natural Resources [VANR]. (2014). Universal recycling materials management map. Retrieved from http://anrmaps.vermont.gov/websites/Organics/default.html

Waste and Resources Action Programme, UK [WRAP]. (2013). Household food and drink waste in the United Kingdom 2012.

Retrieved from http://www.wrap.org.uk/sites/files/wrap/hhfdw-2012-summary.pdf 


\section{Appendix. Histogram of Supply-Demand-Index for Chicago Communities}

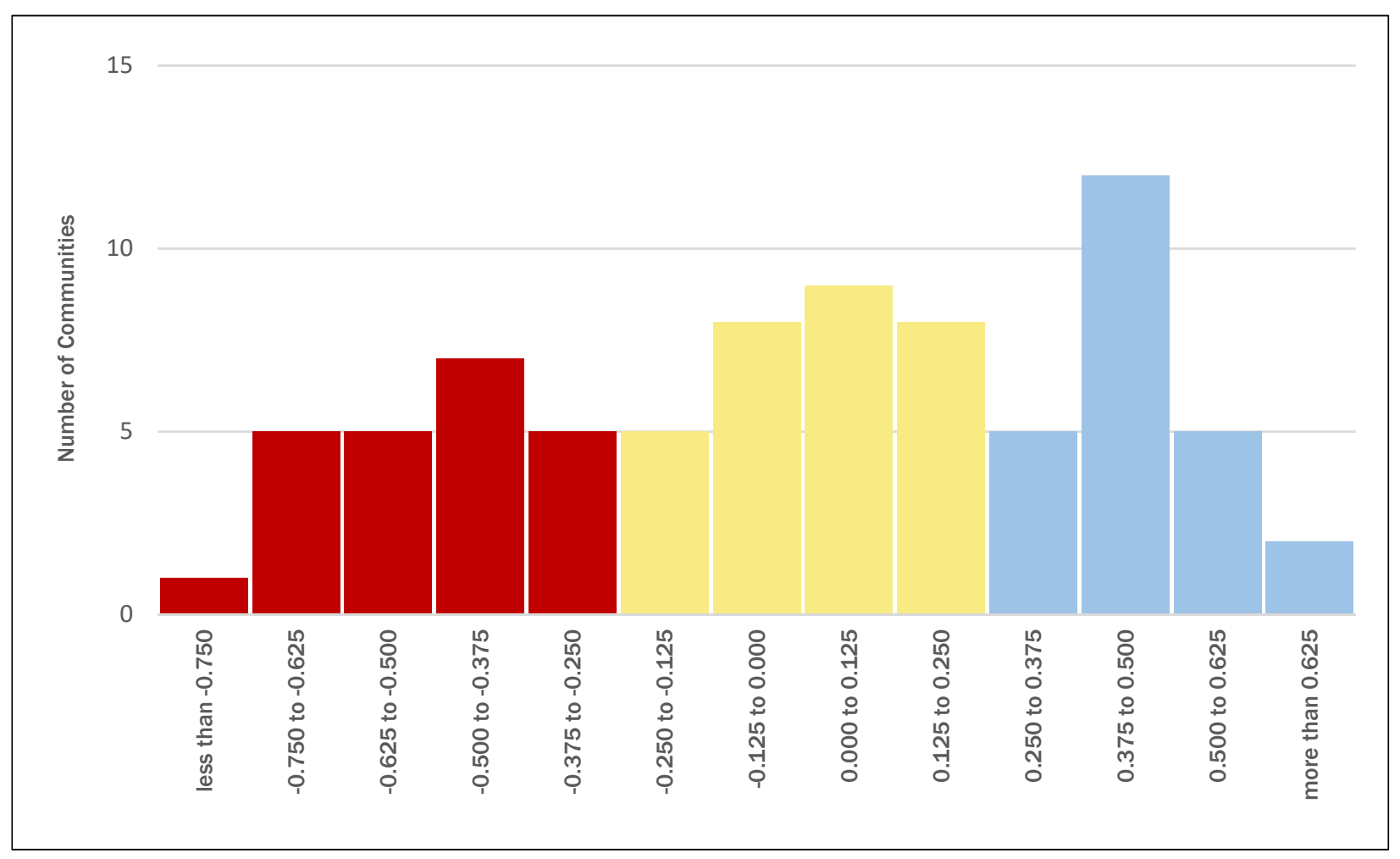

